\title{
BEST PRACTICE MENGAJARKAN MATERI DIKLAT DENGAN MENGGUNAKAN MODUL PENGHITUNGAN TICKET PENERBANGAN INTERNASIONAL DI MASA PANDEMI BAGI GURU SMK-UPW
}

\author{
VIVERAWATI \\ Widyaiswara BBPPMPV Bisnis \& Pariwisata \\ Email : viverawati.sunarto@gmail.com
}

\begin{abstract}
ABSTRAK
Dimasa pandemi ini seluruh dunia, tidak terkecuali pendidikan di Indonesia terkena dampaknya. Begitu juga yang dialami para peserta Diklat guru SMK untuk Program Keahlian UPW (Usaha Perjalanan Wisata). Pelatihan dilakukan secara virtual, disela-sela kesibukannya mengajar siswanya secara daring. Tujuan Best Practice ini, penulis melaporkan hasil pembelajaran teori maupun praktek secara jarak jauh dan daring. Menggunakan materi diklat berupa modul, yakni Modul Diklat Penghitungan Harga tiket Penerbangan Internasional secara Manual memperlihatkan peningkatan hasil belajar yang signifikan dari hasil pre test dan post yang dilakukan peserta Diklat Program Upskilling dan Reskilling Guru Kejuruan berstandar Industri. Di dalam Modul Diklat tersebut, berisi cuplikan dari perlengkapan Praktek yang terdiri buku-buku dan cara menggunakan buku-buku tersebut. Guru SMK-UPW yang mengikuti pelatihan secara online, dapat mengakses modul tersebut. Selama pandemi, peserta diklat harus dapat mengusahakan sendiri kaitannya dengan pengadaan buku-buku World Wide Air Tarif, General rule, dan Official Airline Guide yang sebagai alat praktek yang sangat diperlukan dalam proses Belajar materi diklat. Intisari buku-buku tersebut dirangkum dalam modul Diklat sebagai sarana belajar pengetahuan penghitungan harga tiket penerbangan Internasional yang sangat basic/mendasar. Walaupun saat ini, kita sudah dihadapkan pada era yang serba komputerisasi \& digital. Penguasaan teori yang salah satu sumber utamanya didapatkan dari peralatan praktek untuk materi diklat berupa buku-buku seperti disebutkan di atas, menjadi pembeda dari seorang karyawan Travel Agent yang berlatar belakang pendidikan lulusan SMKUPW.
\end{abstract}

Kata kunci : Keterampilan proses, Mengajar, Materi Diklat Tiket Penerbangan Internasional, Masa Pandemi.

\section{PENDAHULUAN}

Wabah virus corona atau yang dikenal COVID-19 telah menjadi pandemic di dunia dengan kecepatan penyebaran yang tinggi, dan berdasarkan data WHO diperoleh bahwa COVID-19 telah menjadi pandemic global. Dampak yang ditimbulkan dari pandemi COVID19 telah mengubah berbagai aspek kehidupan manusia. Beberapa kebijakan telah diambil Pemerintah untuk mengantisipasi penyebaran yang tidak terkendali seperti pemberlakuan social distancing, physical distancing, Pembatasan Sosial Berskala Besar (PSBB) hingga Pemberlakuan Pembatasan Kegiatan Masyarakat (PPKM) melalui Instruksi Menteri Dalam Negeri Nomor 01 Tahun 2021 tentang pemberlakuan Pembatasan Kegiatan Masyarakat untuk pengendalian penyebaran COVID-19. Kebijakan-kebijakan tersebut membatasi kegiatan masyarakat seperti bekerja, beribadah, bersekolah hingga berwisata.

Pelatihan Guru menjadi salah satu kegiatan yang dibatasi, artinya proses pembelajaran tidak diperbolehkan tatap muka antara Widyaiswara dan peserta Diklat, proses pembelajaran dilakukan dari rumah. Proses pembelajaran pada masa pendemi Covid-19 memiliki tantangan yang tidak mudah bagi para Widyaiswara. Bekerja dari rumah dan belajar dari rumah merupakan kebijakan yang diambil dalam mengatasi penyebaran virus Covid-19 pada masa pandemi ini. Dalam kondisi wabah virus ini, kegiatan pembelajaran diharapkan tetap berjalan dalam rangka meningkatkan kompetensi peserta Diklat. 
Pembelajaran online adalah langkah yang harus diambil untuk menghindari penyebaran virus pada klaster Pusat Pendidikan \& Pelatihan Guru. Perubahan pola belajar mengajar ini menuntut Widyaiswara dan peserta Diklatnya untuk dapat berinteraksi di dunia maya, dan proses mentransfer pengetahuan dan keterampilan tetap berjalan. Proses belajar mengajar secara online ini juga bukan berarti tidak ada kendala di lapangan. Kendala yang dirasakan adalah keterbatasan sarana atau alat praktek untuk materi Diklat Penghitungan tarif penerbangan Internasional yang sangat sulit ditemui diluaran seperti Toko Buku maupun perpustakaan. Sementara peralatan praktek penghitungan tiket penerbangan Internasional berbentuk buku-buku seperti: World Wide Air Tarif, General rule, dan Official Airline Guide

Masing-masing buku yang disebutkan di atas, merupakan alat praktek bagi guru yang akan mempelajari materi tiket penerbangan Internasional, memiliki fungsi yang berbeda. Seperti:

1. World Wide Air Tarif, terdapat sumber-sumber referensi untuk mempelajari: FCP, Global Indicator, IATA Area, MPM, HIP dan NUC.

2. General rule, terdapat sumber-sumber referensi untuk mempelajari: EMA, TPM, IROE, juga LSF.

3. Official Airline Guide, terdapat sumber-sumber referensi untuk mempelajari waktu keberangkatan dan waktu kedatangan dari kota-kota besar di dunia.

Di dalam materi Penghitungan harga Ticket Penerbangan Internasional, yang harus dipelajari antara lain : Menentukan FCP, Type of Journey (one way / Return), Class of service, NUC, Global Indicator, MPM, TPM, EMA, HIP, AF (Aplicable Fare), IROE (IATA Rate of Exchange), LSF (Local Selling Fare). Buku-buku yang digunakan sebagai perlengkapan praktek pada Mata Diklat Penghitungan Harga Tiket Penerbangan Internasional secara Manual.
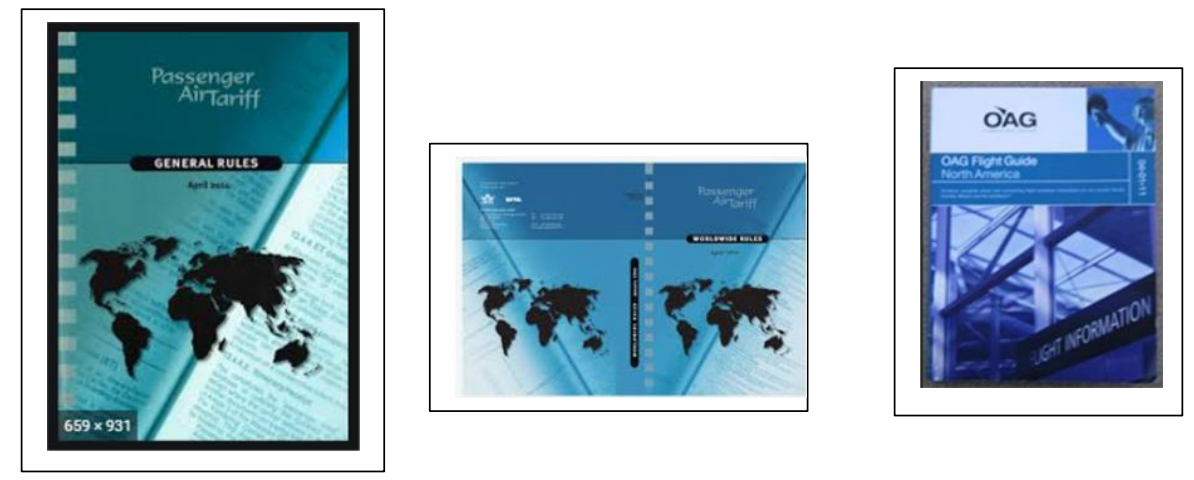

\section{Gambar 1. Buku Penghitungan harga Ticket Penerbangan Internasional}

Output dari pelatihan ini diharapkan guru SMK-UPW memiliki kompetensi Penghitungan Tarif Penerbangan Internasional, yang nantinya ilmu tersebut dapat di transfer ke anak didik yang kelak dapat bekerja di Travek Agent sebagai staf Airline Ticketing. Siswa lulusan dari Program keahlian UPW diharapkan memiliki nilai lebih dari lulusan Sekolah menengah lainnya dalam memahami istilah-istilah yang terdapat dalam terminology dunia penerbangan, juga lebih percaya diri dalam melakukan penghitungan harga tiket penerbangan domestik khususnya. Untuk pengetahuan tentang tiket penerbangan Internasional, harus lebih dari lulusan sekolah menengah lainnya.

Melalui penelitian ini, diharapkan dapat menambah sedikit wawasan pengetahuan bagi guru maupun siswa SMK-UPW dalam memahami materi penghitungan Tarif Penerbangan Internasional. Pentingnya penggunaan buku-buku seperti: World Wide Air Tarif, General rule, dan Official Airline Guide, sebagai acuan dasar untuk belajar penghitungan tarif penerbangan Internasional. Saat mempelajari buku-buku tersebut, tidak mengharuskan kita untuk mempelajari keseluruhan isinya. Cukup pada bagian-bagian tertentu saja, yang berkaitan erat 
dan sangat diperlukan saat kita melakukan penghitungan harga tiket penerbangan Internasional dengan cara manual / tidak komputerisasi. Sebelum tahun 2000 an dimasa belum boomingnya "paperless". Juga belum ramainya digitalisasi, IATA masih menerbitkan buku- buku seperti: World Wide Air Tarif, General rule, dan Official Airline Guide, dalam bentuk hard copy. Dicetak 4x (empat kali) dalam setahun, setiap 3 (tiga) bulan terbit edisi baru dan dibagikan ke seluruh Travel Agent yang menjadi anggota IATA.

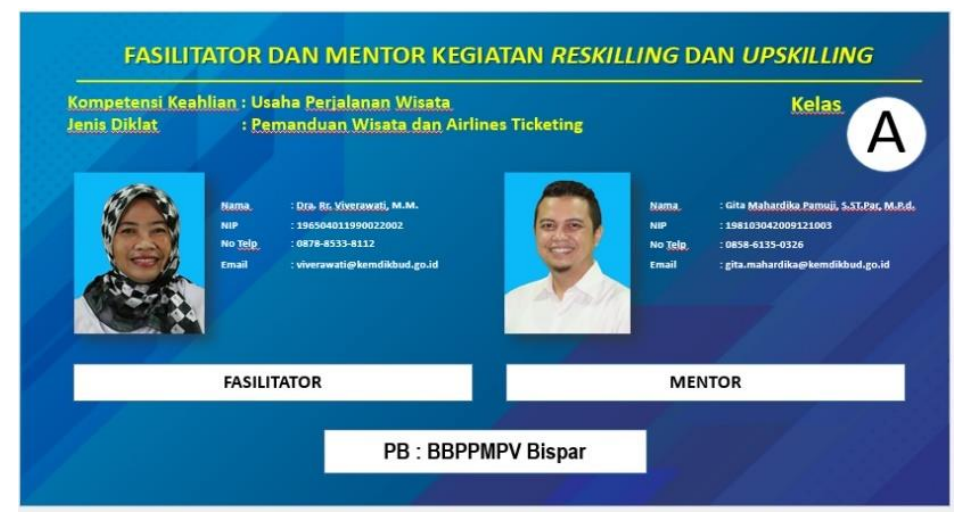

Gambar 3. Kartu Id Card

Untuk saat ini, semua buku cetakan keluaran IATA dapat diakses menggunakan internet. Diberikan pada anggota IATA yang membayar iuran tahunan. Sementara bagi guru, siswa SMK-UPW sebagai penggiat, pengguna layanan informasi dari buku-buku seperti: World Wide Air Tarif, General rule, dan Official Airline Guide. Kita dapat menggunakan cetakan lamanya saja, karena kita dapat memperoleh informasi tentang Global Indicator, IATA Area, MPM, HIP, NUC dan yang lainnya kaitannya untuk menghitung harga tiket penerbangan Internasional, juga mempelajari cara membaca tabel-tabel yang ada di buku tersebut.

Semua materi itu dapat dipelajari dengan menggunakan Modul Penghitungan Tarif Penerbangan Internasional, pada saat mengikuti pelatihan yang diselenggarakan secara online /dalam jaringan bagi guru SMK-UPW melalui program Diklat Up \& Re Skilling yang dilaksanakan pada tanggal 28 September s.d 30 November 2020 dan berlangsung di masa pandemi. Menurut Suprawoto (2009:2) modul adalah sarana pembelajaran dalam bentuk tertulis/cetak yang disusun secara sistematis, memuat materi pembelajaran, metode, tujuan pembelajaran berdasarkan kompetensi dasar atau indikator pencapaian kompetensi, petunjuk kegiatan belajar mandiri (self instructional), dan memberikan kesempatan kepada siswa untuk menguji diri sendiri melalui latihan yang disajikan dalam modul. Dengan demikian, modul berfungsi sebagai sarana belajar yang bersifat mandiri, sehingga siswa dapat belajar sesuai dengan kecepatan masing-masing.

Modul menurut, Purwanto (2007) adalah bahan belajar yang dirancang secara sistematis berdasarkan kurikulum tertentu dan dikemas dalam bentuk satuan pembelajaran terkecil dan memungkinkan dipelajari secara mandiri dalam satuan waktu tertentu.

Pembelajarannya dilaksanakan dengan Jarak jauh, tanpa ruang kelas secara fisik. Pelatihan yang dilaksanakan dengan sistem daring yang memanfaatkan internet. Menurut Bilfaqih \& Qomarudin (2015) "pembelajaran daring merupakan program penyelenggaraan kelas pembelajaran dalam jaringan untuk menjangkau kelompok target yang masif dan luas".

Peserta Diklat Up \& Re Skilling yag diselenggarakan oleh Balai Besar Pengembangan Penjaminan Mutu Pendidikan Vokasi Bisnis \& Pariwisata berasal dari berbagai Propinsi di Indonesia. Menurut Dogmen (2016) ciri-ciri pembelajaran jarak jauh adalah adanya organisasi yang mengatur cara belajar mandiri, materi pembelajaran disampaikan melalui media, dan tidak ada kontak langsung antara penngajar dengan pembelajar. Sistem pembelajaran yang dilaksanakan untuk program Up \& Re Skilling, menggunakan Learning Management Systems. 


\section{METODE PENELITIAN}

Peserta Diklat Program Up \& Re Skilling terdiri dari 19 orang Guru SMK yang berasal dari:

1. Propinsi Sumatera Utara - 2 orang

2. Propinsi Jawa Barat - 7 orang

3. DKI Jakarta - 1 orang

4. Jawa Tengah -3 orang

5. Sulawesi Selatan - 1 orang

6. Kepulauan Riau - 2 orang

7. Sumatera Barat - 2 orang

8. Nusa Tenggara Timur - 1 orang

Tabel 1. Struktur Program Upskilling dan Reskilling Materi Proses Industri Pemanduan Wisata dan Airlines Ticketing

\begin{tabular}{|c|c|c|}
\hline Komponen & Mata Diklat & $\begin{array}{c}\text { Alokasi } \\
\text { Waktu (JP) }\end{array}$ \\
\hline Umum & $\begin{array}{l}\text { 1. Kebijakan Pendidikan Vokasi } \\
\text { 2. Kebijakan Program Upskilling dan Reskilling }\end{array}$ & $\begin{array}{l}1 \\
1\end{array}$ \\
\hline \multirow[t]{4}{*}{ Pokok } & $\begin{aligned} \text { 1. Pembelajaran Daring } \\
\quad \text { Materi Kejuruan } \\
\quad \text { Aspek Pedagogik dan Kewirausahaan } \\
\square \quad \text { Mekanisme Kegiatan Industri }\end{aligned}$ & 54 \\
\hline & $\begin{array}{l}\text { 2. Pendalaman Pendalaman Materi Industri } \\
\square \quad \text { Orientasi Program Proses Kegiatan Industri } \\
\square \quad \text { Pembahasan Refleksi Pembelajaran Daring }\end{array}$ & 60 \\
\hline & $\begin{array}{l}\text { 3. Proses Kegiatan Industri } \\
\quad \text { Implementasi dan Aplikasi } \\
\square \quad \text { Implementasi dan Aplikasi Manajemen }\end{array}$ & 300 \\
\hline & $\begin{array}{l}\text { 4. Uji Sertifikasi keahlian } \\
\square \quad \text { Uji Sertifikasi Kompetensi Keahlian di } \\
\text { Industri } \\
\square \quad \text { Pembahasan dan Penyelesaian Teaching }\end{array}$ & 59 \\
\hline \multirow[t]{4}{*}{ Penunjang } & 1. Pembukaan dan Penutupan & 2 \\
\hline & 2. Penjelasan Umum & 2 \\
\hline & 3. Pre dan Post Test & 1 \\
\hline & TOTAL & 480 \\
\hline
\end{tabular}

Metodologi pembelajaran yang digunakan dalam proses kegiatan ini adalah konstruktivisme, andragogy, dengan menerapkan diskusi kasus, penugasan, ceramah, kerja kelompok yang di lanjutkan dengan Uji Sertifikasi Keahlian.

Pada laporan Best Practice ini akan diuraikan hanya pelatihan yang dilaksanakan dalam pembelajaran Daring, untuk materi kejuruannya. Lebih dikususkan lagi untuk materi Penghitungan Tarif Penerbangan Internasional secara manual. Untuk peserta Diklat dari Guru SMK-UPW akan mempelajari materi yang terdapat pada Modul diklat yang dapat di download dari LMS (Learning Mangement System-untuk Program Up \& Re skilling). Perlu diketahui juga diwaktu yang bersamaan, Balai Besar Pengembangan Penjaminan Mutu Pendidikan Vokasi-Bisnis \& Pariwisata (BBPPMPV- Bisnis \& Pariwisata) menyelenggarakan 11 (sebelas) program Keahlian untuk Diklat Up \& Re skilling kali ini.

Setelah peserta mengikuti seluruh rangkaian diklat yang terdapat pada program Up \& $\mathrm{Re}$ skilling, peserta akan di evaluasi. 


\section{Tujuan Penilaian}

Penilaian terhadap peserta bertujuan untuk mengukur kompetensi peserta melalui ketercapaian indikator kompetensi dan keberhasilan tujuan program. Penilaian dilaksanakan untuk mengukur tingkat penguasaan kompetensi sesuai dengan kompetensi yang dipelajari di industri.

\section{Penilaian Terhadap Peserta}

a. Nilai Sikap (NS)

Penilaian sikap dimaksudkan untuk mengetahui sikap peserta pada aspek kerjasama, disiplin, tanggungjawab, dan keaktifan. Sikap-sikap tersebut dapat diamati pada saat menerima materi di pendampingan tatap muka, melaksanakan tugas individu dan kelompok, mengemukakan pendapat dan bertanya jawab, serta saat berinteraksi dengan fasilitator maupun peserta lain. Pengamatan sikap dilakukan mulai awal sampai akhir kegiatan secara terus menerus. Nilai akhir aspek sikap merupakan kesimpulan fasilitator yang diperoleh dari hasil pengamatan sikap peserta selama kegiatan.

\section{b. Nilai Keterampilan (NK)}

Penilaian keterampilan dimaksudkan untuk mengetahui kemampuan peserta dalam mendemonstrasikan pemahaman dan menerapkan pengetahuan yang diperoleh maupun keterampilan yang mendukung kompetensi dan indikator. Penilaian keterampilan menggunakan pendekatan penilaian autentik mencakup bentuk tes dan non tes. Penilaian aspek keterampilan dilakukan oleh fasilitator melalui penugasan individu dan/atau kelompok yang diselesaikan oleh peserta saat belajar mandiri terstruktur. Komponen yang dinilai dapat berupa hasil Lembar Kerja dan/atau hasil praktik sesuai dengan yang tertuang di Buku Kerja Modul Unit Kompetensi tertentu.

\section{c. Nilai Tes Akhir (TA)}

Nilai pengetahuan diperoleh dari Tes Akhir (TA) yang dilakukan oleh peserta pada akhir kegiatan. Tes mencakup kompetensi profesional yang dipelajari pada setiap bidang keahlian berdasarkan indikator pencapaian kompetensi dari setiap unit kompetensi.

1) Tes dikembangkan dalam bentuk pilihan ganda. Jumlah soal untuk menguji penguasaan materi profesional dalam satu unit kompetensi tergantung pada kedalaman dan karakteristik materi yang dipelajari.

2) Tes dilaksanakan di Pusat Belajar yang memenuhi syarat yang telah ditetapkan secara online dalam LMS.

3) Alokasi waktu tes disesuaikan dengan karakteristik tiap materi. Nilai tes akhir akan digunakan sebagai salah satu komponen nilai akhir peserta.

Selanjutnya, Nilai Akhir (NA) peserta Program Upskilling dan Reskilling bagi Guru Kejurun Berstandar Industri diperoleh dengan formula sebagai berikut:

$$
N A=[\{(N S \times 30 \%)+(\text { NK } \times 70 \%)\} \times 70 \%]+[\text { TAx 30\%] }
$$

Keterangan:

$$
\begin{array}{ll}
\text { NA }=\text { Nilai Akhir } & \text { NS }=\text { Nilai Sikap } \\
\mathrm{NK}=\text { Nilai Ketrampilan } & \text { TA }=\text { Test Akhir }
\end{array}
$$

Berikut adalah kategori predikat yang diterima peserta mengadaptasi Peraturan Kepala Lembaga Administrasi Negara Nomor 15 Tahun 2015 tentang pedoman diklat prajabatan: 
Vol 1. No. 3, Juli 2021 P-ISSN : 2775-0019, e-ISSN : 2774-6283

\begin{tabular}{|c|c|}
\hline Angka & Predikat \\
\hline$>90-100$ & Amat Baik \\
\hline$>80-89.99$ & Baik \\
\hline$>70-79.99$ & Cukup \\
\hline$>60-69.99$ & Sedang \\
\hline$\leq 59.99$ & Kurang \\
\hline
\end{tabular}

Peserta akan mendapatkan Surat Tanda Tamat Pendidikan dan Pelatihan (STTPP) apabila memperoleh nilai dengan predikat minimal Cukup.

\section{HASIL DAN PEMBAHASAN}

Tabel 3. Pelaksanaan kegiatan diklat yang diselenggarakan oleh BBPPMPV

\begin{tabular}{|c|c|c|}
\hline No. & Pelaksanaan Kegiatan & Waktu \\
\hline & Persiapan & \\
\hline 1. & $\begin{array}{l}\text { Pembentukan panitya penyelenggara program Up \& } \\
\text { Reskilling, penentuan admin LMS }\end{array}$ & AUG 2020 \\
\hline 2. & $\begin{array}{l}\text { Penyusunan program, membuka link pendaftaran peserta } \\
\text { Diklat \& menentukan persyaratan peserta diklat, menyusun } \\
\text { kebutuhan bahan \& alat, sarana prasarana }\end{array}$ & AUG 2020 \\
\hline 3. & $\begin{array}{l}\text { Penyusunan program LMS, Pembentukan panitya LMS } \\
\text { Melatih teknisi \& admin dalam mengoperasikan } \\
\text { perlengkapan \& peralatan menggunakan jaringan internet } \\
\text { juga Learning Management System nya. }\end{array}$ & AUG 2020 \\
\hline 4. & $\begin{array}{l}\text { Menentukan Fasilitator \& Mentor Program Up \& Re } \\
\text { Skilling }\end{array}$ & AUG 2020 \\
\hline 5. & Penyusunan modul, soal pre \& post test, Lembar Kerja & AUG 2020 \\
\hline 6. & $\begin{array}{l}\text { Menyusun Panduan Diklat, Menentukan fasilitator \& } \\
\text { Mentor }\end{array}$ & AUG 2020 \\
\hline & Pelaksanaan Diklat & \\
\hline 7. & $\begin{array}{l}\text { Apa bila peserta diklat menemukan kendala dengan } \\
\text { program LMS, dapat menghubungi admin LMS }\end{array}$ & SEP 2020 \\
\hline 8. & $\begin{array}{l}\text { Peserta yang terpilih untuk mengikuti diklat mendapatkan } \\
\text { password \& kode untuk mengakses LMS }\end{array}$ & SEP 2020 \\
\hline 9. & $\begin{array}{l}\text { Peserta mengerjakan setiap tahapan yang terdapat dalam } \\
\text { Smart Training-Learning Management Systems }\end{array}$ & $\begin{array}{l}\text { SEP - } \\
\text { OCT } 2020\end{array}$ \\
\hline 10. & $\begin{array}{l}\text { Peserta mendapatkan modul, mengerjakan soal pre } \& \text { post } \\
\text { test melalui layanan LMS (Learning Management System) }\end{array}$ & SEP 2020 \\
\hline 11. & Peserta dapat mendownload modul diklat, Lembar kerja, & $\begin{array}{l}\text { SEP-OCT } \\
2020\end{array}$ \\
\hline 12. & Meng up load tugas-tugas \& Lembar Kerja & OCT2020 \\
\hline 13. & $\begin{array}{l}\text { Peserta \& Fasilitator seminggu } 2 \text { x mengadakan tatap muka } \\
\text { melalui zoom meeting. }\end{array}$ & OCT 2020 \\
\hline 14. & Diantara sesama peserta diklat memiliki forum diskusi & OCT 2020 \\
\hline & Evaluasi & \\
\hline 15. & $\begin{array}{l}\text { Peserta Diklat mengerjakan pre \& post test yang di unggah } \\
\text { oleh admin LMS }\end{array}$ & $\mathrm{OC}$ \\
\hline
\end{tabular}




\begin{tabular}{|l|l|l|}
\hline 16. & $\begin{array}{l}\text { Peserta mendownload terlebih dahulu tugas-tugas \& Lembar } \\
\text { Kerjanya. }\end{array}$ & $\begin{array}{l}\text { OCT 2020 } \\
\text { Peserta diklat mengerjakan tugas-tugas, Lembar kerja yang } \\
\text { terdapat dalam Modul Diklat yang telah di unggah oleh } \\
\text { admin diklat di dalam LMS. }\end{array}$ \\
\hline 17. & Peserta meng up load semua tugas, LK & OCT 2020 \\
\hline 18. & $\begin{array}{l}\text { Fasilitator akan menilai tugas-tugas \& LK yang telah di up OCT 2020 } \\
\text { load peserta }\end{array}$ & $\begin{array}{l}\text { OCserta akan mendapatkan nilai setelah mengumpulkan OCT 2020 } \\
\text { tugas-tugas \& Lembar Kerjanya }\end{array}$ \\
\hline 19. & & \\
\hline
\end{tabular}

Peserta diklat yang terdiri dari guru-guru SMK-UPW dari seluruh Indonesia, berhasil di input data-data nya sesuai persyaratan \& kriteria yang telah ditetapkan oleh panitya Penyelenggara Diklat dari BBPPMPV Bisnis \& Pariwisata terpilihlah \& dikelompokan menjadi 4 (empat ) kelas. Masing-masing kelas terdiri dari 19 s.d 24 orang guru. Penulis mengampu kelas A, yang memiliki 19 orang peserta. Masing-masing peserta diberi password aga dapat mengakses program-program yang terdapat pada LMS (Learning Management System). Melalui program tersebut, peserta dapat mendownload materi, meng unggah tugas-tugas \& Lembar Kerja yang sudah dikerjakan. Melalui program itu juga, peserta dapat melakukan diskusi anata sesama peserta maupun dengan fasilitatornya. Peserta dapat mengakses program tersebut tahap demi tahap. Pelatihan untuk daringnya berlangsung selama 54 JP @ 45 menit dalam rentanga waktu 21 (dua puluh satu) hari yang berlangsung di bulan Oktober 2020. Peserta dapat membuka program LMS kapan saja dimana saja peserta berada selama masih dalam jangjauan internet di daerah masing-masing. Hanya pertemuan dengan fasilitator hanya berlangsung $2 \mathrm{x}$ dalam seminggu, tiap-tiap pertemuan hanya membutuhkan 1 JP @ 45 menit. Sehingga tidak mengganggu tugas mengajar dari guru / peserta diklat.

Modul Diklat Penghitungan Tarif Penerbangan Internasional yang di unggah admin LMS Program Up \& Re skilling. Untuk di unduh \& dipelajari peserta diklat Program Up \& Re skilling.

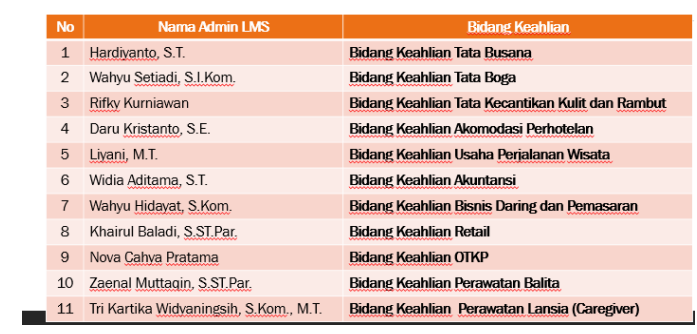

\section{Gambar 3. Admin LMS Program Upskilling dan Reskilling}

Di bawah ini uraian secara singkat dari materi-materi yang terdapat dalam Modul Penghitungan Harga Tiket Penerbangan Internasionl, yang harus dikuasai oleh seorang guru SMK untuk Program keahlian UPW-Usaha Perjalanan Wisata.

1. Menentukan FCP (Fare Construction Point)

2. Type of Journey (one way / Return)

3. Global Indicator

4. NUC (Neutral Unit of Construction).

5. MPM 
1. MPM

Maximum Permited Milleage, merupakan total jarak yang diperkenankan untuk ditempuh dengan menggunakan tarif yang tercantum dalam tabel dari buku Worldwide Air Tariff. MPM dapat dilihat dari tabel, yang juga mencantumkan NUC, di kolom paling kanan bersamaan dengan Global Indicator (GI).

3. TPM

Ticketed Point Milleage, merupakan jarak per sektor dari sebuah itinerary. Tabel yang berisikan cara melihat besarnya TPM untuk tiap2 sektor perjalanan, terdapat dalam buku General Rule dari IATA Air Tariff.

4. EMA (Excess Milleage Allowance)

Excess Milleage Allowance merupakan pengurangan total jarak, apabila dalam route tersebut melewati kota atau area tertentu. Bila di dalam itineray, ternyata total TPM nya melebihi EMA, Agar kelebihan harganya tidak terlalu besar, pertama kali yang harus kita check adalah EMA utk route tersebut.

5. EMS (Extra Milleage Surcharge), merupakan biaya tambahan yang dikenakan bila total TPM melebihi MPM.

6. HIP (Higher Intermediate Point)

7. AF (Aplicable Fare)

Harga akhir yang nantinya akan diterapkan pada saat dilakukan konversi ke mata uang negara keberangkatan. ROE (IATA Rate of Exchange) Nilai tukar mata uang yang berlaku pada saat tiket di issued. Diterbitkan oleh IATA Clearing House. IATA Rate of Exchange, ini sangat diperlukan sekali pada saat akan melakukan pembayaran dengan menggunakan mata uang negara keberangkatan. Rate of Exchange Merubah Local Currency Fare (LCF) menjadi NUC (Neutral Unit of Construction) .

8. LCF (Local Currency Fare)

Merupakan hasil akhir harga ticket dari suatu perjalanan. Mata uang sebenarnya, dari negara dimana perjalanan mulai dilaksanakan.

\section{KESIMPULAN}

Kesimpulan dari penulisan best practice ini adalah :

1. Salah satu strategi dalam Pelaksanaan Program Diklat Rp \& Re skilling bagi guru-guru SMK-UPW adalah mempelajari materi dari modul diklat Penghitungan Tarif Penerbangan Internasional yang telah di up load ke Learning Manajement system, agar dapat di download oleh peserta diklat untuk di pelajari \& di diskusikan sesama peserta Diklat juga dengan fasilitatornya, memberikan dampak yang sangat baik dalam Proses Belajar peserta Diklat. Peserta diklat dapat mempelajari isi modul tersebut, yang berisikan rangkuman cara menggunakan alat praktek yang digunakan dalam materi Penghitungan Tarif Penerbangan Internasional yang terdiri dari beberapa buku seperti: World Wide Air Tarif, General rule, dan Official Airline Guide.

2. Hasil nilai Pre \& Post test peserta Diklat Guru SMK-UPW program Up \& Re Skilling ini menunjukan kenaikan yang signifikan. Hasil Pre test Overall average dari seluruh peserta diklat Up \& Re skilling adalah 68,67. Sedangkan hasil post testnya 77,33.

3. Hasil dari Program Upskilling dan Reskilling Guru Kejuruan berstandar Industri adalah meningkatknya kompetensi bagi guru SMK Kompetensi Proses Industri Pemanduan Wisata dan Airlines Ticketing sesuai dengan standar Industri, Dunia Usaha, dan Dunia Kerja (IDUKA). Keberhasilan penyelenggaraan Program Upskilling dan Reskilling Guru Kejuruan berstandar industri Proses Industri Pemanduan Wisata dan Airlines Ticketing sangat bergantung pada kesungguhan dan partisipasi aktif seluruh komponen yang terlibat dalam kegiatan ini. Hasil-hasil yang dicapai khususnya kemampuan peserta dalam memahami kompetensi dibidangnya akan memberikan pengaruh terhadap agenda, materi, dan strategi penerapan yang dilakukan oleh guru nantinya. Kondisi seperti ini pada gilirannya dapat meningkatkan 
keberhasilan Kompetensi secara keseluruhan menuju peningkatan mutu pendidikan di Indonesia.

\section{DAFTAR PUSTAKA}

Latief, Abdul Madjid. 2012. Evaluasi Program dan Aplikasi. Jakarta: Uhamka Press

Maman Abdurrahman dan Sambas Ali Muhidin. 2011. Panduan Praktis Memahami Peneltian (Bidang Social-Administrasi dan Pendidikan). Bandung: Badan Penerbit Pustaka Setia.

Moh. Yamin. 2015. Teori dan Metode Pembelajaran. Jakarta: Madani

Munir. 2009. Pembelajaran Jarak Jauh Berbasis Teknologi dan Informasi. Bandung: CV. Alfabeta

Purwanto dkk. 2007. Pengembangan Modul. Jakarta: Pustekom

Suharsimi Arikunto. 2006. Prosedur Peneltian: Suatu Pendekatan Praktik. Jakarta: Badan Penerbit Rineka Cipta.

Wirawan. 2011. Evaluasi Teori, Model, Standar, Aplikasi, Dan Profesi. Jakarta : Kharisma Putra Utama.

Yusuf Bilfaqih dan M. Nur Qomarudin. 2016. Esensi Penyusunan Materi Pembelajaran Daring. Yogyakarta : Deepublish 